EVALUATING NUTRITIONAL STATUS OF CHILDREN WITH CANCER (ACUTE LYMPHOBLASTIC LEUKEMIA - ACUTE MYELOID LEUKEMIA) USING TUBE FEEDING

\author{
By \\ Kh. A. Shahin \\ Ahmed K. Sayed \\ Department of Nutrition and Food \\ Department of Nutrition and Food \\ Science \\ Science
}

Research Gournal Specific Fducation

Faculty of Specific Education

glansoura University

ISSUE NO. 48, OCTOBER. 2017

مجلة بحوث التربية النوعية - جامعة المنصورة

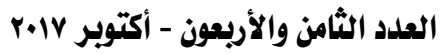




\title{
EVALUATING NUTRITIONAL STATUS OF CHILDREN WITH CANCER (ACUTE LYMPHOBLASTIC LEUKEMIA - ACUTE MYELOID LEUKEMIA) USING TUBE FEEDING
}

\author{
Kh. A. Shahin
}

Ahmed K. Sayed

Abstract

The main objective of this study is to Evaluating nutritional status of children with Cancer (Acute lymphoblastic leukemia - Acute myeloid leukemia) using tube Feeding. The study included 36 Egyptian children diagnosed ALL and AML which is the most common form of childhood cancer leukemia. The study continued for two months. All children were matched for age $(6.92+1.05)$ content of $50 \%$ boys and $50 \%$ girls. Data were collected about Anthropometric measurements, nutritional status and medical tests. The results showed that BMI were indicated normal status and nutritional status score was even more than $100 \%$ of Reference Range. for ALL and AML cases. Hb \& Lymphoblast were higher in AML than ALL. No difference found in the result between ALT and AST. Urea level of AML and ALL Children were in high level, but AML children were more than the upper limit of the Reference Range. The food intakes in the hospital compared with DRI were more than $100 \%$ while the other nutrients were less than DRI, deficiency was particularly evident for selenium $(72.14 \%$ of DRI), followed by Vit.A (75.75\% of DRI) and Vit.C (80.80\% of DRI) .

Key Words: Acute lymphoblastic leukemia - Acute myeloid leukemia -Tube feeding- Dietary Reference Intakes .

\section{INTRODUCTION :}

Leukemia remains the most common type of pediatric cancer $(<15$ years old), and represents $30 \%$ of all childhood cancers (Hunger and Mullighan, 2015). Acute leukemia (AL) accounts for more than $95 \%$ of all childhood leukemia cases, including acute lymphoblastic leukemia (ALL)

* Department of Nutrition and Food Science 
(78\%) and acute myeloid leukemia (AML) (16\%) (Ries et al., 1999 and Puumala et al., 2013).

Nutritional status, represented by body composition, is an important consideration in pediatric clinical conditions as it can impact clinical outcomes factors such as infections, quality of life, long term comorbidities and survival. (Brinksma et al., 2015).

To improve outcomes for pediatric patients, it is important to understand the impact that different conditions may have on nutritional status to allow malnutrition to be effectively treated or potentially prevented. While anthropometry can provide a general indication of a child's growth status or body size in relation to a reference population. (Loeffen $\boldsymbol{e t}$ al., 2015).

Consuming a healthy diet aids in achieving and maintaining a healthy weight and provides nutrients that may aid in preventing cancer, as well as avoidance of foods that may directly or indirectly (through their role in contributing to empty calories) increase cancer risk. (Weinhouse et al., 2010). Those who consume a healthy diet tend to weigh less and have a lower overall cancer incidence. The ACS considers a healthy diet as one that is high in vegetables, fruits, and whole grains; low in red and processed meats, refined grains, sugar, and alcohol; and relies on food, instead of supplements as a source of nutrients. (Kushi et al., 2012).

The enteral feeding should be used for nutritional support whenever possible due to the benefits of enteral feeding . Up to $40-70 \%$ of children with chronic illness are estimated to have feeding issues. Gastric feeding via a naso-gastric (NG) tube is usually the initial approach when the oral route is not suitable. (Farrelly et al., 2016).

Tube feeding, via a nasogastric tube may be an efficient way of nutritionally supporting patients with extreme anorexia or dysphagia caused by a head and neck tumor or with an or pharyngeal-esophageal mucositis due to radiation therapy and/or chemotherapy. to achieve good results in allowing the proper completion of the oncologic therapy. (Sharp et al., 2016). 


\section{MATERIALS AND METHODS:}

The research sample of Present Work was taken from the Children's at Cairo Cancer Hospital. The sample size amounted to (36) children, Group 1 are (18) children diagnosed with Acute lymphoblastic leukemia (ALL) and Group 2 are (18) children diagnosed with Acute myeloid leukemia (AML), both of them are using tube Feeding and have been giving food from Menu of the hospital.

\section{Biochemical Analysis:}

Blood and liver glucose levels were determined by the method of (Trinder. 1959), using Stanbio enzymatic glucose procedure. Serum total lipids were determined in $\mathbf{m g} / \mathbf{d l}$ according to the method described by (Kinight . 1977).

Serum triglycerides (T.G) were determined as $\mathrm{mg} / \mathrm{dl}$ according to the method described by (Fossati and Principe . 1982).

Serum total cholesterol was determined as $\mathrm{mg} / \mathrm{dl} \%$ according to the colorimetric method of (White et al., 1970).

Serum high density lipoprotein cholesterol (HDL-c) was determined as $\mathrm{mg} / \mathrm{dl}$ according to the method described by (Richmond. 1973).

Serum low density lipoprotein cholesterol (LDL-c) was calculated as $\mathrm{mg} / \mathrm{dl}$ according to (Castelli et al., 1977) equation:

LDL - c Concentration $(\mathrm{mg} / \mathrm{dl})=($ Total Cholestesterol $)-(\mathrm{HDL}-\mathrm{c})-(\mathrm{VLDL}-\mathrm{c})$ Serum Very low density lipoprotein cholesterol (VLDL-c) was calculated as $\mathrm{mg} / \mathrm{dl}$ according to (Srivastava et al.,2002) equation:

$$
\text { VLDL - C Concentration } \mathrm{mg} / \mathrm{dl}=\frac{T G}{5}
$$

Serum Glutamate Oxaloacelate Transaminase (S. Got) or (AST) was determined as unit/l according to (Chawla. 2003).

Serum Glutamate Pyruvate Transaminase (SGPT) or (ALT) was determined as unit/l according to (Srivastava et al., 2002).

Serum urea was determined as $\mathrm{mg} / \mathrm{dl}$ according to the method described by (Malhotra 2003). 
- Evaluating nutritional status of children with Cancer (Acute lymphoblastic leukemia -

Serum creatinine was determined as $\mathrm{mg} / \mathrm{dl}$ according to (Chary and Sharma. 2004).

Colorimetric method was used to determine uric acid according to the method by (Ohkawa et al., 1979).

Nutrition status score was calculated as follows:

Nutritional statues score (Gomez) $=\frac{\text { Current Weight }}{I B W} \times 100$

(Serajul et al., 2008)

Ideal Body Weight for Children was calculated as follows :

$I B W=\left(\right.$ Age $\left.e^{*}\right)+8$ (Geoffrey. 1995).

Statistical Analysis:

Statistical Analysis were performed by using computer program statistical package for social (SPSS) and compared with each other using the suite tests. All obtained results were tabulated. Statistical Analysis has been achieved using IMP-P-C computer by SPSS, program (SPSS, 1998).

\section{Results and Discussion:}

Table (1) shows Demographic, anthropometric and Nutritional Status score data of different studied patient. The Weight, Height and BMI were No difference found in the results between them. Nutritional Status Score was even more than $100 \%$ of Reference Range for ALL and AML patient, also Body fat was more than the Reference Range, indicating for better status. Nutritional status, represented by body composition, is an important consideration in pediatric clinical conditions as it can impact clinical outcomes factors such as infections, quality of life, long term comorbidities and survival. (Bechard. et al., 2016). Also (Brinksma et al., 2015). showd that Optimal nutritional status is vital in children with clinical conditions to improve short term clinical outcomes and long term health.

Table (2) shows $\mathrm{CBC}$ and glucose of different studied patient.The hemoglobin mean value $(\mathrm{g} / \mathrm{dL})$ was little bit high for AML patient (11.5 \pm 0.33$)$ and for ALL patient was $(11.4 \pm 0.32)$ but both of them in the normal Reference Range. WBCs status for AML patient was $(7 \pm 0.63)$ 
higher than ALL patient (6.4 \pm 0.37$)$ also Lymphoblasts for AML patient was(6505.6 \pm 3.28$)$ higher than ALL patient (6455.6 \pm 3.11$)$, this may indicate for the different chemotherapy protocol they use. Anemia is a frequently encountered complication in cancer, and is associated with fatigue and reduced quality of life. Retrospective analyses of data from patients with hematological malignancies and solid tumors provide evidence that a low baseline hemoglobin $(\mathrm{Hb})$ level is a prognostic factor for poor outcome. (Caro et al., 2011).

Table (3) shows Lipid profile. All values quantified for lipid profile paranters (TC, TG, VLDL, LDL and also HDL) No difference found in the results between ALL patient and AML patient. Also all values were in the normal Reference Range. In recent years, MS-based lipidomic approaches have been increasingly employed in the search for lipid biomarkers as diagnostic tools for different diseases. Lipids are the building blocks of membranes which form the barriers between the cells. They are involved in signal transduction and nutrient exchange, and establish the contact sites during host-pathogen interactions. Alterations in lipid profiles are used for the diagnosis of hereditary disorders of lipid metabolism including Gaucher disease and acquired disorders such as diabetes. (Hu et al., 2009).

Table (4) shows the activity of liver enzymes. The ALT mean value of children with Acute myeloid leukemia cancer (AML) (20.2 \pm 3.28$)$ was higher than the upper ALT mean value for children with Acute lymphoblastic leukemia (ALL) $(17.6 \pm 1.82)$, also AST mean value of children with Acute myeloid leukemia cancer (AML) (21.1 \pm 2.76 ) was higher than the upper AST mean value for children with Acute lymphoblastic leukemia (ALL) (19.3 \pm 2.54$)$. but both of them were in the normal Reference Range. Liver function biomarkers (gamma-glutamyl transferase, GGT; alanine aminotransferase, ALT; aspartate aminotransferase, AST; alkaline phosphatase, ALP; total bilirubin) are used in clinical diagnosis of various disorders, including those related to liver function impairment and damage. (Hall et al., 2012). The normal level of alanine aminotransferase (ALT) or aspartate aminotransferase (AST) are indications of normal functioning of liver cells and normal level of alkaline 
phosphatase (ALP) shows that there is sufficient level of albumin for the production of protein. (Rahmioglu et al., 2009).

Table (5) shows the kidney function parameters. Creatinine and Uric acid levels were No difference found in the results between children with Acute myeloid leukemia cancer (AML) and children with Acute lymphoblastic leukemia (ALL), while Urea mean levels (18.3 \pm 2.78 ) were more than the upper limit of Reference Range for children with Acute myeloid leukemia cancer (AML), also Urea mean levels (16.6 \pm 4.23 ) for children with Acute lymphoblastic leukemia (ALL) were near the upper limit of Reference Range. calling for more medical care for children with cancer to avoid losses in the renal function. As many chemotherapy agents undergo renal clearance and require dose adjustment with renal insufficiency. (Chawla et al., 2016). They state that cancer patient should be re-evaluated for resolution of kidney function and receive good care. (Chertow et al., 2005).

Table (6) shows food intake. The percentage of Energy, Carbohydrate, Total Protein and Total Fat compared with DRI for children with Acute myeloid leukemia cancer (AML) and children with Acute lymphoblastic leukemia (ALL) were more than the DRI. This indicated that hospital menu was good. While the percentage of Vit. A, Vit. C and Selenium were less than the DRI for children with Acute myeloid leukemia cancer (AML) and children with Acute lymphoblastic leukemia (ALL). This calls for the challenge to feed patients with possibly more nutrients concentrated food, along with awareness programs. "Nutrition" is defined as "the science of food ... in relation to health and disease" (WHO, 2002). "Food" is not specifically defined by US agencies. In general, it is a substance that enters the stomach, provides energy, and/or sustains normal metabolism. Minimum daily requirements of food categories (proteins, elements, and vitamins), now called Dietary Reference Intake amounts, have been established (Food and Nutrition Board, 2010). 


\section{مجلة بحوث التربية النوعية - علد}

Table (1) : Demographic, anthropometric and Nutritional Status score and body fat data for children with cancer Acute lymphoblastic leukemia (ALL) and Acute myeloid leukemia (AML). Result are expressed as (Mean $\pm \mathrm{SD}$ ).

\begin{tabular}{|c|c|c|c|}
\hline \multirow[b]{2}{*}{ Parameter } & \multicolumn{3}{|c|}{ children with Cancer } \\
\hline & $\begin{array}{c}\text { ALL 4-8y } \\
(\mathrm{N}=18) \text { Mean } \pm \\
\text { SD }\end{array}$ & $\begin{array}{c}\text { AML 4-8y } \\
(\mathrm{N}=18) \text { Mean } \pm \\
\text { SD }\end{array}$ & Ref. Range \\
\hline Age (y) & $6.8 \pm 1.04$ & $7 \pm 1.08$ & $(4-8)$ \\
\hline Weight (kg) & $22.4 \pm 1.62$ & $22.4 \pm 1.97$ & $(16-24)$ \\
\hline Hight $(\mathrm{m})$ & $1.1 \pm 0.09$ & $1.1 \pm .10$ & 1.15 \\
\hline BMI (kg/m2) & $19 \pm 3.69$ & $19.3 \pm 3.27$ & $(12.1-21.2)$ \\
\hline Nutritional Status Score \% & $103.6 \pm 6.79$ & $102.4 \pm 9.79$ & $(90 \%-100 \%)$ \\
\hline Body fat $\%$ & $19 \pm 5.40$ & $19.2 \pm 4.71$ & $15 \%$ \\
\hline
\end{tabular}

Table (2): $\mathrm{CBC}$ and glucose for children with cancer Acute lymphoblastic leukemia (ALL) and Acute myeloid leukemia (AML). Result are expressed as (Mean $\pm \mathrm{SD})$.

\begin{tabular}{|c|c|c|c|}
\hline \multirow[b]{2}{*}{ Parameter } & \multicolumn{3}{|c|}{ children with Cancer } \\
\hline & $\begin{array}{c}\text { ALL 4-8y Mean } \\
\pm \text { SD }\end{array}$ & $\begin{array}{c}\text { AML 4-8y Mean } \\
\pm \text { SD }\end{array}$ & Ref. Range \\
\hline $\mathrm{Hb}(\mathrm{g} / \mathrm{dL})$ & $11.4 \pm 0.32$ & $11.5 \pm 0.33$ & $(11.0-14.0)$ \\
\hline WBCs $(\{10\} 3$ cell $/ \mathrm{ml})$ & $6.4 \pm 0.37$ & $7 \pm 0.63$ & $(4.5-10.5)$ \\
\hline Lymphoblasts & $6455.6 \pm 3.11$ & $6505.6 \pm 3.28$ & $(6000-9000)$ \\
\hline Lymphoblasts \% & $6.5 \pm 0.31$ & $6.5 \pm 0.33$ & $(6-9) \%$ \\
\hline Glucose $(\mathrm{mg} / \mathrm{dL})$ & $89.8 \pm 7.63$ & $85.6 \pm 6.06$ & $(70-110)$ \\
\hline
\end{tabular}


Table (3) : Lipid profile (Cholesterol, Triglycerides, HDL, LDL, VLDL and Atherogenic Index) for children with cancer Acute lymphoblastic leukemia (ALL) and Acute myeloid leukemia (AML). Result are expressed as (Mean $\pm \mathrm{SD}$ ).

\begin{tabular}{|c|c|c|c|}
\hline \multirow[b]{2}{*}{ Parameter } & \multicolumn{3}{|c|}{ children with Cancer } \\
\hline & $\begin{array}{c}\text { ALL 4-8y } \\
\text { Mean } \pm \text { SD }\end{array}$ & $\begin{array}{c}\text { AML 4-8y } \\
\text { Mean } \pm \text { SD }\end{array}$ & Ref. Range \\
\hline Cholesterol (mg/dL) & $140.3 \pm 3.94$ & $139.9 \pm 2.90$ & $(135-200)$ \\
\hline Triglycerides (mg/dL) & $34.8 \pm 1.85$ & $35.7 \pm 1.11$ & $(20-150)$ \\
\hline $\operatorname{HDL}(\mathrm{mg} / \mathrm{dL})$ & $58 \pm 3.28$ & $60.2 \pm 2.61$ & $(38-75)$ \\
\hline $\mathrm{LDL}(\mathrm{mg} / \mathrm{dL})$ & $70.7 \pm 2.59$ & $71 \pm 2.56$ & $(64-130)$ \\
\hline $\operatorname{VLDL}(\mathrm{mg} / \mathrm{dL})(\operatorname{Tr} / 5)$ & $6.9 \pm 0.98$ & $7 \pm 0.91$ & $(4-30)$ \\
\hline Atherogenic Index (AI) Ratio (LDL/HDL) & $1.2 \pm 0.07$ & $1.2 \pm 0.07$ & $(1.78-2.13)$ \\
\hline
\end{tabular}

Table (4) : Liver function $\{\mathrm{ALT}(\mathrm{GPT})$ and AST(GOT) $\}$ for children with cancer Acute lymphoblastic leukemia (ALL) and Acute myeloid leukemia (AML). Result are expressed as (Mean $\pm \mathrm{SD}$ ).

\begin{tabular}{||c|c|c|c||}
\hline \multirow{2}{*}{ Parameter } & \multicolumn{3}{|c||}{ children with Cancer } \\
\cline { 2 - 5 } & ALL 4-8y & AML 4-8y & Ref. Range \\
& Mean \pm SD & Mean \pm SD & \\
\hline \hline ALT(GPT) $(\mathrm{u} / \mathrm{L})$ & $17.6 \pm 1.82$ & $20.2 \pm 3.28$ & $\mathbf{( 7 - 4 0 )}$ \\
\hline AST(GOT) $(\mathrm{u} / \mathrm{L})$ & $19.3 \pm 2.54$ & $21.1 \pm 2.76$ & $\mathbf{( 7 - 3 7 )}$ \\
\hline
\end{tabular}


Table (5) : Kidney function (Creatinine, Urea and Uric Acid) for children with cancer Acute lymphoblastic leukemia (ALL) and Acute myeloid leukemia (AML). Result are expressed as (Mean $\pm \mathrm{SD})$.

\begin{tabular}{||l|c|c|c||}
\hline \multirow{2}{*}{\multicolumn{1}{|c|}{ Parameter }} & \multicolumn{3}{|c||}{ children with Cancer } \\
\cline { 2 - 4 } & ALL 4-8y & AML 4-8y & \multirow{2}{*||}{ Ref. Range } \\
& Mean \pm SD & Mean \pm SD & (0.3-0.9) \\
\hline Creatinine (mg/dL) & $0.7 \pm 0.07$ & $0.7 \pm 0.08$ & $\mathbf{( 7 - 1 7 )}$ \\
\hline Urea (mg/dL) & $16.6 \pm 4.23$ & $18.3 \pm 2.78$ & $\mathbf{( 2 - 7 )}$ \\
\hline Uric Acid (mg/dL) & $3.8 \pm 0.56$ & $3.9 \pm 0.42$ & The \\
\hline
\end{tabular}

Table (6) : Food intake (Energy, Carbohydrate, Total Protein, Total Fat, Vit. A , Vit. C, Vit. E and Selenium) for children with cancer Acute lymphoblastic leukemia (ALL) and Acute myeloid leukemia (AML). Result are expressed as (Mean $\pm \mathrm{SD})$.

\begin{tabular}{|c|c|c|c|c|c|}
\hline \multirow{3}{*}{ Parameter } & \multicolumn{5}{|c|}{ children with Cancer } \\
\hline & \multicolumn{2}{|c|}{ ALL 4-8y } & \multicolumn{2}{|c|}{ AML 4-8y } & \multirow{2}{*}{ *DRI } \\
\hline & Mean \pm SD & $\%$ & Mean \pm SD & $\%$ & \\
\hline Energy (kcal/day) & $1522.39 \pm 95.68$ & 125.04 & $1507.58 \pm 141.91$ & 123.82 & 1217.57 \\
\hline Carbohydrate $(\mathrm{g} / \mathrm{d})$ & $209.33 \pm 13.16$ & 125.1 & $207.29 \pm 19.51$ & 123.88 & 167.33 \\
\hline Total Protein $(\mathrm{g} / \mathrm{d})$ & $76.12 \pm 4.78$ & 125.05 & $75.38 \pm 7.10$ & 123.84 & 60.87 \\
\hline Total Fat (g/d) & $42.29 \pm 2.66$ & 127.07 & $41.88 \pm 3.94$ & 125.83 & 33.28 \\
\hline Vit. A (mg/d) & $304.48 \pm 19.14$ & 76.12 & $301.52 \pm 28.38$ & 75.38 & 400 \\
\hline Vit. C (mg/d) & $20.30 \pm 1.28$ & 81.19 & $20.10 \pm 1.89$ & 80.4 & 25 \\
\hline Vit. E (mg/d) & $6.92 \pm 0.43$ & 98.86 & $6.85 \pm .0 .65$ & 97.89 & 7 \\
\hline Selenium (ug/d) & $21.75 \pm 1.37$ & 72.49 & $21.54 \pm 2.03$ & 71.79 & 30 \\
\hline
\end{tabular}

\section{REFERENCES :}

- Bechard, L. J.; Duggan, C.; Touger-Decker, R.; Parrott, J. S.; RothpletzPuglia, P. and Byham-Gray, L.(2016): Nutritional Status Based on Body Mass Index Is Associated With Morbidity and Mortality in Mechanically Ventilated Critically Ill Children in the PICU Crit Care Med. 
- Brinksma, A.; Roodbol, P.F.; Sulkers, E.; Kamps,W.; Bont, A. E. and Boot, A.M. (2015) : Changes in nutritional status in childhood cancer patients: A prospective cohort study Clin Nutr, 34 (1) , pp. 66-73

- Brinksma, A.; Sanderman, R.; Roodbol, P.; Sulkers, E.; Burgerhof, J. and Bont, E. (2015) : Malnutrition is associated with worse health-related quality of life in children with cancer. Support Care Cancer; 23(10):3043-3052.

- Caro, J. J.; Salas, M.; Ward, A. and Goss, G.(2011): Anemia as an independent prognostic factor for survival in patients with cancer: a systemic, quantitative review. Cancer, 91, pp. 2214-2221.

- Castelli, W. (1977): Determination of LDL. Sclavo Diagnostics, (Made in Italy). Circulation, 55: 767-769.

- Chary, T. M. and Sharma, H. (2004): Practical Biochemistry for Medical and Dental Students. Jaypee Brothers Medical Publishers (p) LTD, New Delhi.

- Chawla, L.S. and Ronco, C. (2016): Renal stress testing in the assessment of kidney disease Kidney Int Rep, 1, pp. 57-63.

- Chawla, R. (2003): Practical Clinical Biochemistry .Third Edition. Jaypee Brothers Medical Publichers (p) LTD, New Delhi.

- Chertow, G.M.; Burdick, E. and Honour, M. (2005): Acute kidney injury, mortality, length of stay, and costs in hospitalized patients J Am Soc Nephrol, 16, pp. 3365-3370

- Farrelly, J. S. and Stitelman, D. H.(2016): Complications in pediatric enteral and vascular access Semin Pediatr Surg, 25, pp. 371-379.

- Food and Nutrition Board (2010): Institute of Medicine, National Academies.

- Fossati, P. and Principe, L. (1982). Serum triglycerides determined colorimetrically. with an enzyme that produces hydrogen peroxide. Clin. Chem., 28: 2077-2080.

- Geoffrey, P.W. (1995): Nutrition: A Health Promotion Approach. 1st. ed, Edward Arnold PLC. London, Sydney Auckland.

- Hall, P. and Cash, J. (2012): What is the real function of the liver 'function' tests? Ulster Med. J., 81 (1), pp. 30-36.

- Hu, C.; Wang, M. and Hankemeier, T. G.(2009): Analytical strategies in lipidomics and applications in disease biomarker discovery 877 (2009), pp. 2836-2846. 
- Hunger, S. P. and Mullighan, C. G. (2015): Acute lymphoblastic leukemia in children. N. Engl. J. Med. 373, 1541-1552. http://dx.doi.org/10.1056/NEJMra1400972.

- Kinight, J. (1977): Determination of total lipids. Bicon Diagnostics (made in Germany). Clinical Chemistry, 18:199-200.

- Kushi, L. H.; Doyle, C. and McCullough, M.(2012): American Cancer Society guidelines on nutrition and physical activity for cancer prevention: reducing the risk of cancer with healthy food choices and physical activity. CA Cancer J Clin;62:30-67.

- Loeffen, E. A.; Brinksma, A.; Miedema, K. G.; Bock, G.H. and Tissing, W. J.(2015): Clinical implications of malnutrition in childhood cancer patientsinfections and mortality. Support Care Cancer;23(1):143-150.

- Malhotra, V. K. (2003): Practical Biochemistry for Students, Fourth Edition, Jaypee Brothers Medical Publishers (p) LTD, New Delhi.

- Ohkawa, H. ; Ohishi, N. and Yagi, K. (1979): Assay for lipid peroxidation in animal tissues by thiobarbituric acid reaction. Annals of Biochemistry , 95:351358.

- Puumala, S. E.; Ross, J. A.; Aplenc, R. and Spector, L. G.(2013): Epidemiology of childhood acute myeloid leukemia. Pediatr. Blood Cancer 60, 728-733. http://dx.doi.org/10. 1002/pbc.24464.

- Rahmioglu, N.; Andrew, T.; Cherkas, L.; Surdulescu, G.; Swaminatha, R. and Spector, T. (2009) : Epidemiology and genetic epidemiology of the liver function test proteins. PLoS ONE, 11 , p. 4435. [4(2)].

- Richmond, N. (1973): Colorimetric method of determination of total cholesterol and high density lipoprotein cholesterol (HDL-c). Clin-Chem., 19:1350-1356.

- Ries, L. A. G.; Smith, M. A.; Gurney, J. G.; Linet, M.; Tamra, T.; Young, J. L. and Bunin, G. R.(1999): Cancer Incidence and Survival among Children and Adolescents: United States SEER Program 1975-1995. National Cancer Institute, SEER Program. NIH Pub. No. 99-4649 Bethesda, MD.

- Serajul, M.d.; Chowdhury, I.; Nayeema, A.; Mahmudul, H.; Rehana, A. and Nazibun, N. (2008): Serum Total Protein and Albumin Levels in Different Grades of Protein Energy Malnutrition; Journal of Bangladesh Society of Physiologist, (3):58-60. 
- Sharp, W. G.; Volkert, V. M. and Scahill, L.(2016): A systematic review and meta-analysis of intensive multidisciplinary intervention for pediatric feeding disorders: J Pediatr, 181, pp. 116-124.

- SPSS (1998): Statistical Pakage for Social Science. Computer Software, Ver.10.,SPSS Company, London, UK.

- Srivastava, L. M.; Das, N. and Sinha, S. (2002): Essentials of Practical Biochemistry. CBC Publishers and Distributors.

- Trinder, P. (1959): Determination of glucose in blood using glucose oxidase with an alternative oxygen acceptor. Annals of Clinical Biochemistry, vol. 6, no. 1, pp. 24-27.

- Weinhouse, S.; Bal, D. G. and Adamson, R. (2010): American Cancer Society guidelines on diet, nutrition, and cancer. The Work Study Group on Diet, Nutrition, and Cancer. CA Cancer J Clin; 41:334-338.

- White, B.; Erickson, M. and Stevens, S. (1970): Determination of Total Cholesterol, Bicon Diagnostics, (Made in Germany). Chemistry For Medical Technologists. Saint Louis.

- World Health Organization (2002): National Cancer Control Programmers .

Geneva: World Health Organization. 


\section{- الحالة الغذائية للأطفال المصابين بالسرطان (ابيضاض الدم الييمفاوى الحاد -}

\section{ابيضاض الدم النخاعى الحاد) المعتمدين على التغذية الانبوبية.}

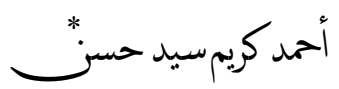

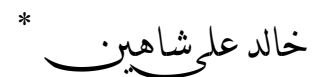

الملخص العربي

الهـدف الرئيسى مـن هـذه الدراسـة هـو تقيـيم الحـالـة الغذائيـة للاطفـال المصابين بالسرطان

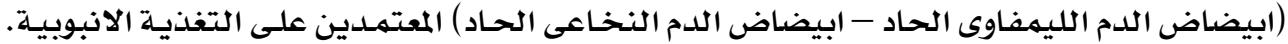
وشملت الدراسة جس طفل مصرى مصاب بالسرطان (وكان عدد المرضى من كل تشخيص || مـريض،

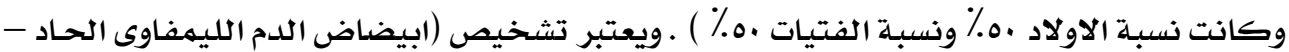

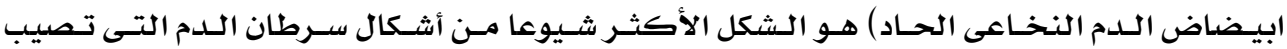

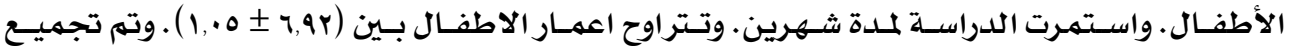

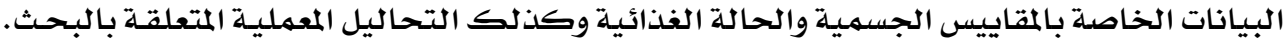

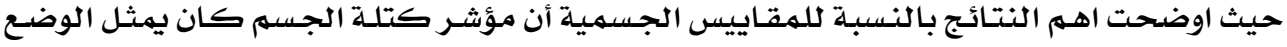

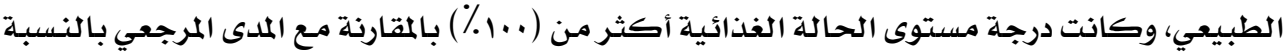

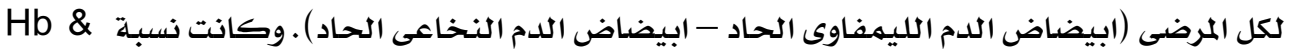
Lymphoblast

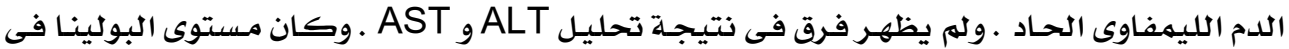

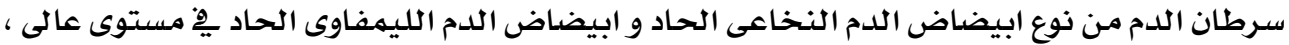

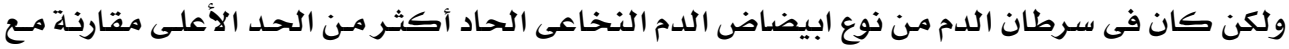

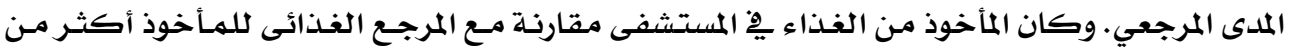

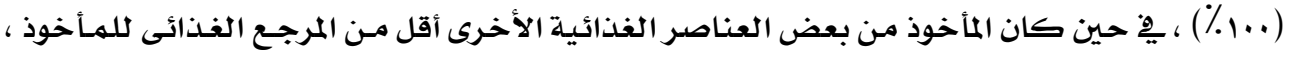

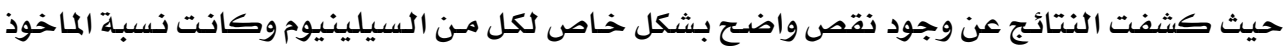

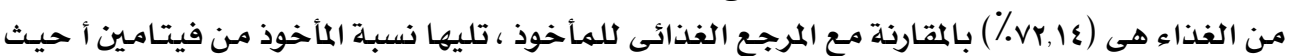

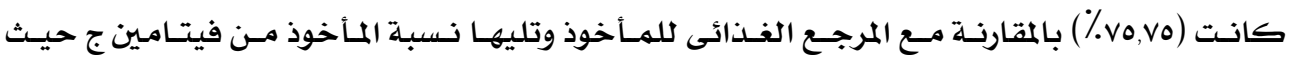

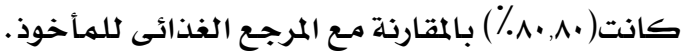

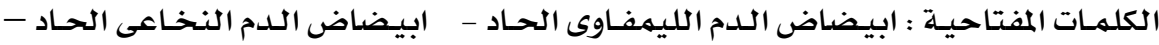

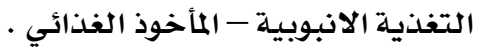

قسم التغذية وعلوم الأطعمة . كلية الاقتصاد المنزلى ـ جامعة المنوفية 